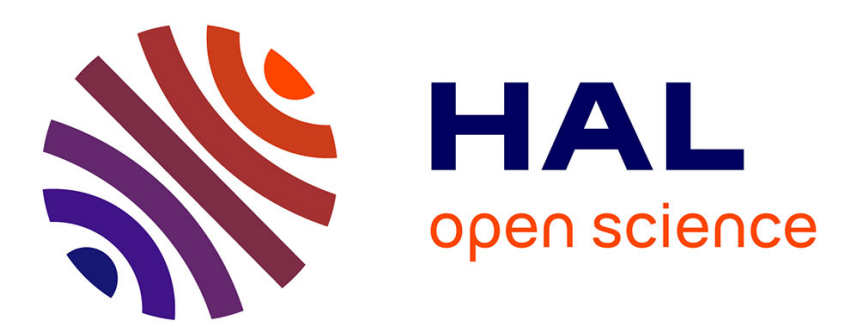

\title{
Determination of bismuth down to sub PG/G level in Greenland snow by laser excited atomic fluorescence spectrometry
}

\author{
J.-P. Candelone, M. Bolshov, S. Rudniev, S. Hong, C. Boutron
}

\section{To cite this version:}

J.-P. Candelone, M. Bolshov, S. Rudniev, S. Hong, C. Boutron. Determination of bismuth down to sub PG/G level in Greenland snow by laser excited atomic fluorescence spectrometry. Journal de Physique IV Proceedings, 1994, 04 (C4), pp.C4-661-C4-664. 10.1051/jp4:19944175 . jpa-00252633

HAL Id: jpa-00252633

https://hal.science/jpa-00252633

Submitted on 1 Jan 1994

HAL is a multi-disciplinary open access archive for the deposit and dissemination of scientific research documents, whether they are published or not. The documents may come from teaching and research institutions in France or abroad, or from public or private research centers.
L'archive ouverte pluridisciplinaire HAL, est destinée au dépôt et à la diffusion de documents scientifiques de niveau recherche, publiés ou non, émanant des établissements d'enseignement et de recherche français ou étrangers, des laboratoires publics ou privés. 


\title{
Determination of bismuth down to sub PG/G level in Greenland snow by laser excited atomic fluorescence spectrometry
}

\author{
J.-P. CANDELONE*, M.A. BOLSHOV**, S.N: RUDNIEV ${ }^{* *}$, S. HONG* and C.F. BOUTRON*,*** \\ * Laboratoire de Glaciologie et Géophysique de l'Environnement du CNRS, 54 rue Molière, Domaine \\ Universitaire, BP. 96, 38402 St Martin d'Hères, France \\ ${ }^{* *}$ Institute of Spectroscopy, Russia Academy of Sciences, Troitzk 142092, Moscow Region, Russia \\ *** UFR de Mécanique, Université Joseph Fourier de Grenoble, Domaine Universitaire, BP. 68, 38041 \\ Grenoble, France
}

\begin{abstract}
We present here preliminary data on the first direct determination of $\mathrm{Bi}$ in Greenland recent snow down to the sub pg/g level by Laser Excited Atomic Fluorescence (LEAF) spectrometry in clean room conditions. Calibration of the spectrometer was achieved using ultralow concentration Bi standards (concentration range $0.05-50 \mathrm{pg} / \mathrm{g}$ ). The limit of detection was found to be $2.5 \mathrm{fg} \mathrm{Bi}$. Various Greenland samples were analysed, giving Bi concentration values in good agreement with these anticipated from the available volcanic emissions data.
\end{abstract}

\section{Introduction}

The investigation of the occurrence of heavy metals in the dated ice and snow layers accumulated in Antarctica and Greenland has proven to be an outstanding way to understand the past natural large scale atmospheric cycles of these metals and to evaluate their present alteration by man $/ 1,2 /$. This has been beautifully illustrated during the past few years in a series of comprehensive studies for various metals $/ 3-8 /$.

Such studies however represent a formidable analytical challenge. This is mainly because heavy metals are present in polar ice and snow at extremely low concentration levels, down to the sub pg/g level. Reliable data can then be obtained only if stringent control of contamination is achieved from field sampling to laboratory analysis and if ultrasensitive spectrometric techniques are used.

Main attention has until now been given to the metals $-\mathrm{Pb}, \mathrm{Hg}, \mathrm{Cd}$ and $\mathrm{Zn}$ - which are the most influenced by human activities $19,10 \%$. On the other hand, little attention has been paid to the metals whose atmospheric cycles are likely to be still undisturbed by man, although such metals can be extremely interesting tracers of specific natural sources and of atmospheric transport pathways. Among these last metals is Bismuth (Bi). Although the available data on the occurrence of this heavy metal in the atmosphere and more generally in the environment are scarce, it is indeed likely that $B i$ is an excellent tracer of volcanic emissions to the atmosphere, since emissions from other natural sources are very limited /11-13/. Investigating the occurrence of this metal in the frozen atmospheric archives stored in the Antarctic and Greenland ice caps could then provide with very valuable time series of volcanic activity in both hemispheres and with pertinent data on the transport patterns of volcanic aerosols in the atmosphere.

Despite this interest, there are presently no data at all on $\mathrm{Bi}$ in Antarctic and Greenland ice and snow. This is especially because Bi concentrations in polar ice and snow were anticipated to be so low, at the sub $\mathrm{pg} / \mathrm{g}$ level, that no sensitive enough analytical technique was available. We present here preliminary results on the determination of $\mathrm{Bi}$ in Greenland recent snow using the ultrasensitive Laser Excited Atomic Fluorescence (LEAF) technique. 


\section{Experimental conditions}

The Bi measurements were performed using the LAFAS-1 automated LEAF spectrometer developed at the Institute of Spectroscopy /14/. The radiation source is a tunable dye laser pumped by an excimer $\mathrm{XeCl}$ laser. Radiation of the dye laser is frequency doubled in a KDP or KBS non-linear crystal. The melted snow sample $(50 \mu \mathrm{l})$ is introduced into a Ringsdorff pyrolitically coated graphite cup inside the electro-thermal atomizer (ETA). The fluorescence radiation is collected through a monochromator onto a photomultiplier whose output signal is digitized using an A/D converter. To minimize contamination problems, the whole spectrometer is located inside a specially designed room supplied with filtered air. In addition, the electro-thermal atomizer and the bench onto which the samples and standards are handled, are placed inside a clean chamber flushed with a laminar flow of air filtered through high efficiency particulate air filters $/ 14 /$.

Extensive investigations were conducted to determine the best analytical schemes for effective excitation and detection of $\mathrm{Bi}$ atomic fluorescence /15/. The best sensitivity was achieved with excitation at $\lambda_{1}=223.061 \mathrm{~nm}$ and fluorescence detection at $\lambda_{2}=299.334 \mathrm{~nm}$. The working conditions for the electro-thermal atomizer were also optimized to reduce the severe spectral and matrix interferences problems which were faced for the Greenland snow samples $/ 15 /$. The best conditions were found to be as follows: after being introduced into the graphite cup of the atomizer with an Eppendorf micropipette, the sample $(50 \mu \mathrm{l})$ was first evaporated $\left(95^{\circ} \mathrm{C}\right.$ for $\left.120 \mathrm{~s}\right)$ and charred $\left(300^{\circ} \mathrm{C}\right.$ for $\left.8 \mathrm{~s}\right)$ with the atomizer being filled with air at atmospheric pressure. The chamber of the atomizer was then closed, evacuated and filled with Argon. The sample was charred again at a slightly higher temperature $\left(400^{\circ} \mathrm{C}\right.$ for $4 \mathrm{~s})$ and then atomized $\left(1200^{\circ} \mathrm{C}\right.$ for $\left.4 \mathrm{~s}\right) / 15 /$.

\section{Calibration of the spectrometer down to sub $\mathrm{pg} / \mathrm{g}$ level}

The calibration of the spectrometer for $\mathrm{Bi}$ was performed using ultralow concentration aqueous standards. $\mathrm{Bi}$ concentrations in these standards ranged from 0.05 to $50 \mathrm{pg} \mathrm{Bi/g}$. They were prepared in the clean laboratory $/ 16 /$ of the Laboratoire de Glaciologie et Geophysique de l'Environnement by successive dilutions of a $1000 \mathrm{ppm} \mathrm{Bi}$ certified atomic absorption standard with ultrapure water $/ 16 /$ using ultraclean procedures. The standards were immediately acidified to make $0.1 \% \mathrm{HNO}_{3}$ solutions using high purity double distilled $\mathrm{HNO}_{3}$ from US National

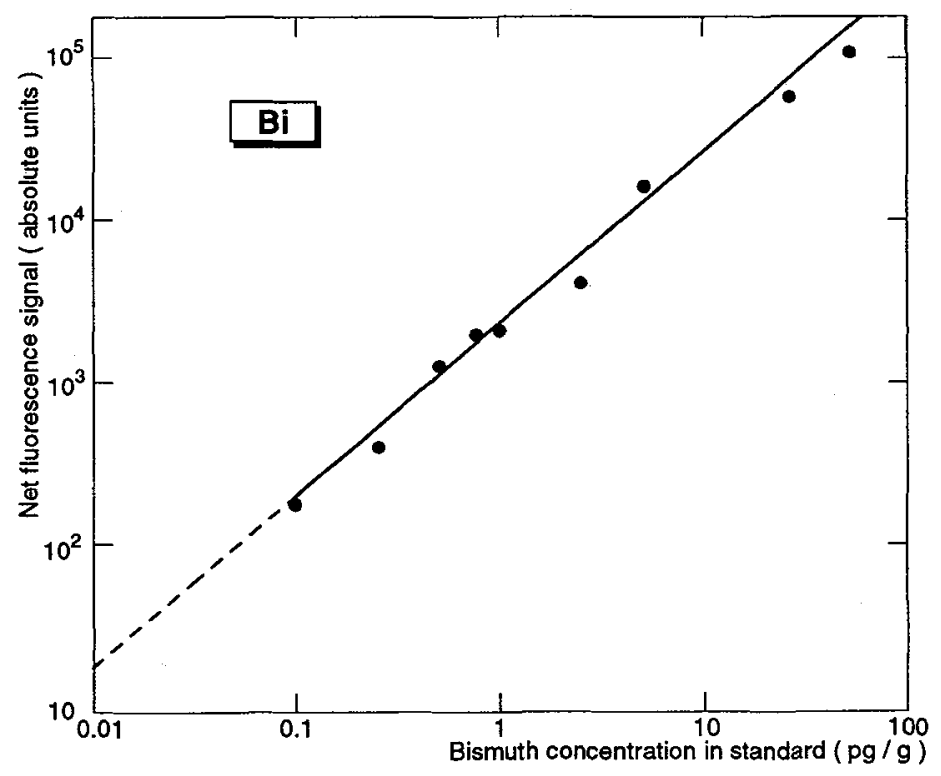

Figure 1. Calibration of the LAFAS-1 spectrometer for Bi using ultralow concentration $0.1 \% \mathrm{HNO}_{3}$ aqueous standards. 
Institute of Standards and Technology (N.I.S.T.) /17/. They were transferred into ultraclean /16/ conventional polyethylene (CPE) bottles and immediately frozen. They were then transported frozen to the Institute of Spectroscopy, packed inside sealed acid cleaned polyethylene bags. They were kept frozen until use in order to minimize possible exchanges (losses or additions) with the walls of the CPE bottles.

The Bi standards (and the samples) were allowed to melt only when really needed for the analyses. Although they remained in liquid state during limited time periods only, there was concern that Bi concentrations might be affected by significant exchanges, especially losses, with the walls of the CPE bottles. In order to quantitatively assess these possible exchanges, several aliquots of the $1 \mathrm{pg} \mathrm{Bi} / \mathrm{g}$ standard were analysed after being left melted during periods of time ranging from thirty minutes to one week. Bi concentrations were found not to deviate significantly from the initial $1 \mathrm{pg} \mathrm{Bi} / \mathrm{g}$ value, then confirming the stability of our ultralow concentration $\mathrm{Bi}$ standards.

The calibration curve so obtained is shown in Fig. 1. The limit of detection (LOD) was found to be $0.05 \mathrm{pg} \mathrm{Bi/g}$ (for $50 \mu$ injections), which corresponds to $2.5 \mathrm{fg} \mathrm{Bi}$. This is by far the lowest LOD ever reported by Bi: it is indeed several orders of magnitude lower than the LODs reported for other analytical techniques.

\section{Analysis of Greenland snow samples}

Two series of Greenland snow samples have been analysed. The first series was surface snow (first $5 \mathrm{~cm}$ or so from the surface) collected in May 1987 at two locations in central Greenland /18/ by pushing ultraclean wide mouth $11 \mathrm{CPE}$ bottles horizontally into the snow. A few typical results are shown in Table 1.

\begin{tabular}{cccc}
\hline Reference of the sample & $\begin{array}{c}\text { Sampling } \\
\text { location }\end{array}$ & $\begin{array}{c}\text { Sampling } \\
\text { date }\end{array}$ & $\begin{array}{c}\mathrm{Bi} \\
(\mathrm{pg} / \mathrm{g})\end{array}$ \\
\hline 56 & $72^{\circ} 21^{\prime} \mathrm{N}$ & May 13, 1987 & 0.38 \\
57 & $40^{\circ} 13^{\prime} \mathrm{W}$ & id. & 0.66 \\
109 & & id. & 0.27 \\
58 & & May 28, 1987 & $<0.05$ \\
53 & $7^{\circ} 59^{\prime} \mathrm{N}$ & id. & $<0.05$ \\
110 & $37^{\circ} 42^{\prime} \mathrm{W}$ & id. & 0.12 \\
\hline
\end{tabular}

Table 1. Bi concentrations measured in a few samples of surface snow collected in central Greenland in May 1987.

Bi concentrations are found to range from $<0.05 \mathrm{pg} / \mathrm{g}$ to $0.66 \mathrm{pg} / \mathrm{g}$, i.e. values in good agreement with what was anticipated from the few available data on Bi emissions from volcanoes on a global scale /11-13/. All the measurements were performed using $50 \mu \mathrm{l}$ injections, without any preliminary preconcentration or chemical treatment. All samples were $0.1 \%$ NIST $\mathrm{HNO}_{3} / 17 \%$.

The samples in the second series were various section of a $10.7 \mathrm{~m}$ snow core drilled in July 1989 at Summit $\left(72^{\circ}\right.$ $35^{\prime} \mathrm{N}, 37^{\circ} 38^{\prime} \mathrm{W}$, elevation $3230 \mathrm{~m}$ ) in central Greenland as part of the european Eurocore programme. This core covered a continuous sequence of 22 years (1967-1989). It was hand drilled by operators wearing full clean room clothing using a specially designed all plastic acid cleaned mechanical auger $/ 5 /$. Despite the exceptional cleanliness of this drilling procedure, it could not be excluded that slight heavy metals contamination might be present on the outside of the core sections. Each section was then mechanically decontaminated in the laboratory using ultraclean methods $15,16 /$, allowing to keep for $\mathrm{Bi}$ analyses only the most central part of each core section. Bi data obtained for a few typical sections are shown in Table 2. Analysis of various additional snow or ice samples covering much longer time periods is planned in the near future. Before such comprehensive analyses are undertaken, it will however be necessary to further improve the LOD, for instance by using a two-step scheme for the excitation. 


\begin{tabular}{cccc}
\hline Reference of the sample & Depth $(\mathrm{m})$ & Age & Bi $(\mathrm{pg} / \mathrm{g})$ \\
\hline EU3H & $2.41-2.56$ & 1985 & $<0.05$ \\
EU5H & $4.47-4.56$ & 1981 & 0.3 \\
EU5B & $4.56-4.72$ & 1980 & 0.07 \\
EU7H & $6.00-6.16$ & 1978 & 0.2 \\
EU12H & $9.58-9.74$ & 1969 & 0.4 \\
\hline
\end{tabular}

Table 2. Bi concentrations measured in various sections of a 10.7 snow core drilled at Summit, central Greenland.

\section{Acknowledgements}

We thank P.Mayewski, C. Rado and R. Delmas for their participation in field sampling, and V. Koloshnikov, G. Turk, J. Brust and F. Hartmann for their continuous interest and stimulating discussions. This work was supported by the Commission of European Communities and Switzerland within the framework of Cost 611 as part of the Eurocore programme, the Division of Polar Programmes of the US National Science Foundation, the Ministere de l'Environnement, the Institut National des Sciences de l'Univers, the University of Grenoble, and the Markon Ltd compagny.

\section{References}

1. Wolff, EW, Antarct Sci 2 (1990) 189.

2. Boutron, CF, Candelone, JP, Hong, $S$, Geochim Cosmochim Acta, in press.

3. Boutron, CF, Patterson, CC, Nature 323 (1986) 222.

4. Boutron, CF, Patterson, CC, Barkov, NI, Earth Planet Sci Lett 101 (1990) 248.

5. Boutron, CF, Görlach, U, Candelone, JP, Bolshov, MA, Delmas, RJ, Nature 353 (1991) 153.

6. Vandal, GM, Fitzgerald, WF, Boutron, CF, Candelone, JP, Nature 362 (1993) 621.

7. Rosman, KJR, Chisholm, W, Boutron, CF, Candelone, JP, Görlach, U, Nature 362 (1993) 333.

8. Boutron, CF, Rudniev, SN, Bolshov, MA, Koloshnikov, VG, Patterson, CC, Barkov, NI, Earth Planet Sci Lett 117 (1993) 431.

9. Nriagu, JO, Pacyna, JM, Nature 323 (1988) 134.

10. Nriagu, JO, Nature 338 (1989) 47.

11. Patterson, CC, Settle, DM, Geochim Cosmochim Acta 51 (1987) 675.

12. Lambert, G, Le Cloarec, MF, Pennsisi, M, Geochim Cosmochim Acta 52 (1988) 39.

13. Le Cloarec, MF, Allard, P, Ardouin, B, Giggenbach, WF, Sheppard, DS, Earth Planet Sci Lett 108 (1992) 19.

14. Apatin, VM, Arkhangelskii, BV, Bolshov, MA, Ermolov, VV, Koloshnikov, VG, Kompanetz, ON, Kutznetsov, NI, Mikhailov, EL, Shishkovskii, VS, Boutron, CF, Spectrochim Acta 44B (1989) 253.

15. Bolshov, MA, Rudniev, SN, Candelone, JP, Hong, S, Boutron, CF, Spectrochim Acta B, in press.

16. Boutron, CF, Fresenius Z Anal Chem 337 (1990) 482.

17. Paulsen, PJ, Beary, ES, Bushee, DS, Moody, JR, Anal Chem 60 (1988) 971.

18. Görlach, U, Boutron, CF, Proceed $7^{\text {th }}$ Int Conf on Heavy Metals in the Environ, Vernet, JP, Ed, Page Bros, Norwich, England (1989) 24. 